\title{
The Relationship Between Social Support and Resilience in Qur'an Memorizing at Santri SMP ISR in Malang City
}

\section{Fitri Shofi Nuraini Dwiputri, and Yudi Tri Harsono}

Psychology, State University of Malang, Malang, Indonesia

ORCID

Fitri Shofi Nuraini Dwiptri; https://orcid.org/0000-0003-3097-0502

\begin{abstract}
This study aimed to determine the relationship between social support and resilience in Islamic students who memorize the Qur'an at Junior High School ISR Malang City. The sample consisted of 110 students who were in the process of memorizing the Qur'an. Data were collected using a questionnaire consisting of two scales, namely the social support scale and the resilience scale. The social support scale, called the Multidimensional Scale of Perceived Social Support (MSPSS), consisted of 12 items, and was developed by Zimet et al. and adapted by Eva \& Bisri. The resilience scale, called the Adolescent Resilience Scale, consisted of 21 items, and was developed by Oshio et al. and adapted by the researchers. Data were analyzed using Pearson's product-moment correlation, resulting in a correlation coefficient of $0.675(p<0.05)$ which fell into the high and unidirectional categories. The results of this study therefore indicated a relationship between social support and resilience in Islamic students who memorize the Qur'an at SMP ISR Malang.
\end{abstract}

Corresponding Author: Fitri Shof Nuraini Dwiptri; email: fitri.shofi.1708116@students. um.ac.id

\section{Dates}

Published 28 January 2022

Publishing services provided by Knowledge

(c) Fitri Shofi Nuraini

Dwiputri, and Yudi Tri

Harsono. This article is

distributed under the terms of the Creative Commons

Attribution License, which permits unrestricted use and redistribution provided that the original author and source are credited

Selection and Peer-review unde the responsibility of the ICoPsy Conference Committee.
Keywords: social support, resilience, Santri, memorizing the Qur'an

\section{Introduction}

Indonesia, the majority of the people are Muslim, has a high interest in memorizing the Qur'an. This is evidenced by the large number of students who memorize the Qur'an in Indonesia. Statistical data on the distribution of Islamic boarding schools from the Kementrian Agama, shows that there are around 4,173,494 students and 27,722 Islamic boarding schools spread throughout Indonesia. Santri memorizing the Qur'an refers to people who are studying religion and are in the process or program of memorizing the Qur'an [1]. Students who memorize the Qur'an at the youth level have similar activities to other teenagers, they study at school like students in general, it's just that their additional task of repeating and memorizing the Qur'an is a challenge for them. This was also expressed by $\mathrm{N}$ through the author's interview who stated that every day the activities of the santri had started when the dawn call to prayer sounded, then they prayed, and continued with ngaos (interpreting the book) until 6 am, after which they cleaned up and had breakfast. After having breakfast and cleaning themselves, they go 
to school until $2 \mathrm{pm}$ then after Asr the cottage activities continue until $7 \mathrm{pm}$. Therefore, being a memorizer of the Qur'an in addition to requiring adequate cognitive abilities, memorizing the Qur'an also requires strong determination and intention, inner and outer readiness, willingness, and good self-regulation [2].

The process of memorizing the Qur'an requires patience, patience, and strong determination. The memorizers of the Qur'an should take their time to add and repeat the memorization they have. Chairani \& Subandi, stated that the process undertaken by memorizing the Qur'an is very long and not easy, this is because a memorizer of the Qur'an must memorize 114 suras, 6236 verses, 77,439 words, and 323,015 symbols, based on the results of preliminary research conducted on 6 students [2]. memorizing the Qur'an in a Tahfidzul Quran found that the most difficult thing in memorizing the Qur'an is "keeping". The meaning of keeping is not only keeping it memorized so it doesn't get lost but also maintaining behavior following the guidance of the Qur'an.

Through interviews conducted by the author to the principal of SMP ISR Malang City, the challenge faced by students when memorizing the Qur'an is the loss of memorization, in this case also related to maintaining the memorization they already have bored with the process of memorizing the Qur'an, even one of the students felt inferior. with his friend who reads two to three times immediately memorized then immediately deposited the memorization while he did not, therefore the student was deliberately absent three times and did not enter the Qur'an class.

The picture above shows that being a santri who memorizes the Qur'an, especially when teenagers, requires resilience to be able to carry out their obligations as students as well as students. Resilience in the field of psychology is better known as resilience. Resilience includes coping and adaptation mechanisms when individuals are faced with problems, high-risk stressors. Individual stress drives coping stress to be able to work, then coping stress will lead individuals to be able to determine steps and adapt to the situation, appropriate stress coping will lead individuals to positive adaptation and positive adaptation produces resilient individuals [3].

Being a teenager is a stage of transition from childhood to adulthood. This stage is often referred to as a stage full of conflict so that it makes memorizing the Qur'an, especially youth memorizing the Qur'an, struggle more in achieving the predetermined target. This is in line with Hall's statement in Santrock which states that adolescence is a time of turmoil, conflict, and mood swings [4]. Santrock also states that adolescent development is influenced by genetic and environmental factors [4]. In fact, in seeking knowledge, the average student spends most of his time in the boarding school environment, this is because the students live in the dormitory and require them to be 
away from their parents, the statement expressed by $\mathrm{R}$ through the author's interview stated that while staying in the dormitory they came home when semester holidays and during major celebrations such as Eid al-Fitr, and Eid al-Adha. Santri is also required to share rooms with other students so that in one room there are 4 to 5 students. Such conditions cause adolescents to experience dramatic changes in development so that conflicts often occur at this stage.

The explanation above is a description of the lives of students who are in the program of memorizing the Qur'an at SMP ISR Malang City. Addonizioin his writing states that most students will say they are stressed and depressed, this is a side effect of pursuing higher education both inside and outside the classroom, changing the educational or school environment, and working at the same time [5]. Similar to the condition of students who are memorizing the Qur'an, they are faced with dense activities, strict regulations, demands for memorization, assignments from school, conflicts between fellow students.

Addonizioin also states that social support has the effect of reducing stress and other factors that cause fatigue in the field of education [5]. This is also expressed by Lawson and Fuechrer which states that social support received by students can be stress coping to cope with severe stress [6]. For students, social support can be obtained through friends, parents, classmates, and teachers [7].

Optimal social support can minimize the risk of depression in adolescents and affect the developmental stage of individuals who receive such support, for example, the support provided by parents will be very valuable for early and late adolescents [8]. Baron \& Byrne, mention that together with other people (family, friends, partners) can reduce anxiety, this is because there is coping that is formed and centered on emotions, in addition to family and friends who can help solve problems there is a centered coping on the problem [9]. Taylor states that family support can calm emotionally, and reduce anxiety because the support provided by family members is more open and effective [10]. Social support describes emotional experiences that are sourced and available from others. Social support is one of the tactics in reducing the stress that involves the social side of life. Social support can be obtained from family or friends, although social support is not always effective for every individual, social support is an alternative that can be used to reduce stress and protect personal health [11].

Previous literature conducted by Rojas concluded that social support in the form of guidance and family support contributed greatly to student resilience, this study also stated that factors from within the individual also affect the level of resilience in students [12]. Sambu which researched individuals who were victims of fires in Kiambaa Village, 
Kenya. Showing the results that there is a significant positive correlation between social support and resilience, this study also states that social support is the key to building resilience in traumatized victims [13].

Research with social support and resilience variables has been discussed on several subjects while research on the subject of students memorizing the Qur'an in Indonesia has not been studied to author's knowledge, when viewed from the number, Indonesia has a high interest in memorizing the Qur'an as many as 30 thousand people while research with social support variables and the author's resilience is taken because there is an interesting phenomenon, namely, although there are many obstacles for students who memorize the Qur'an in completing their memorization targets, in the end, they still try to continue to rise after events that according to some students are traumatic such as losing their memorization and this research is expected to develop literature with the subject of memorizing. Qur'an, especially in the city of Malang. The hypothesis is that there is a relationship between social support and resilience in students who memorize the Qur'an at SMP ISR Malang City.

Based on several previous studies that have been carried out with students as research subjects, as far as the authors know, the authors have not found any research with students, especially students who memorize the Koran with research variables, namely social support and resilience.

\section{Literature Review}

\subsection{Resilience}

Grothberg defined resilience as an individual's capacity to be able to handle, face, eliminate, learn and turn difficult experiences into strength [14]. The resilience perspective is based on a fundamental system that can identify individual functions and make significant adaptations to stressors and threatening situations [15]. Oshio et al., describe resilience as a state of a person who can adapt well to the environment. indicates a stable state after a stressful and potentially traumatic event occurred in their life [16].

Resilience in adolescents includes three components: Novelty Seeking is the ability of individuals to become interested in new things and try to do a variety of activities. Emotional regulation is the ability or tendency of individuals to control and control their own emotions appropriately. Positive Future Orientation is a hope for a positive future or a bright future and moving to face the future[17]. 
The sources of resilience are divided into 3, namely sources based on personality factors on the source of resilience including personality characteristics, self-efficacy, selfesteem, internal locus of control, optimism, intellectual capacity, positive self-concept, spirituality, cognitive flexibility, age, gender, race, and ethnicity, adaptability, and expectations [18]. Biological factors indicate that the initial environment will affect the structure of brain development, function, and neurobiological systems, changes that occur in brain size, nervous tissue, receptor sensitivity and synthesis, and reabsorption of neurotransmitters. Physical changes in the brain can affect a person's resilience to be lower, and environmental factors include social support, including relationships with family and peers, secure attachment to mother, family stability, secure relationships with parents who are not busy, good parenting skills. , the absence of depression in the mother, the presence or absence of addictive substance abuse that will have an impact on behavioral problems, and better psychological well-being in children who are abused, at the macro systemic level, community factors, such as good schools, community services, sports opportunities and artistic, cultural factors, spirituality and religion, and lack of exposure to violence will contribute to the level of individual resilience

\section{Social Support}

Social support refers to actions in the form of help or comfort offered by other people or groups to someone [19]. Malecki and Demary define social support as an individual's perception of general support or certain supportive behaviors from people in their social network, which enhances their functioning and sustains them from adverse outcomes [20]. The existence of social support will make individuals feel loved and valued [21]. General support or specific support behaviors are broadly defined and include emotional, instrumental, informational, and appraisal support. Social support is a support received by individuals from people close to the individual, including support from family, support from friends, and support from influential people [22]. Several factors that influence social support including [23]:

1. (a) Social support provider

Social support provided by someone who understands the problems faced by social support recipients will be more effective than social support provided by strangers.

1. (a) Types of social support

The type of social support provided to individuals receiving social support will be effective if it is by the situation and need's they need. 
1. (a) Social support recipient

Characteristics of social support recipients will affect the effectiveness of social support given to someone as an individual receiving social support.

1. (a) Problems faced

The problems faced by individuals receiving social support will have an impact on whether the social support provided is following the problems being faced.

1. (a) Social support time

Social support will run optimally if social support is given at the right time and situation to someone who needs social support.

\section{Method}

The research approach used in this research is a quantitative approach with the research objective of knowing the relationship between social support and resilience in students memorizing the Qur'an at SMP ISR Malang City, Resilience as variable Y, and social support as variable $X$. The research subjects were students who memorized the Qur'an at SMP ISR Malang City totaling 110 people, the subject was obtained by using a combined sample technique with the criteria Male/female, 13-16 years old, registered as students of SMP ISR Malang City, in the process of memorizing the Qur'an at least 1-5 Juz, and Willing to be the subject of research.

The combination sampling technique in this study will combine 2 sampling techniques, namely the proportional sampling technique by taking individuals in each group according to a proportionate portion which will then be combined with a stratified sampling technique because in this study the population is divided into 3 strata or 3 levels.

There are 2 instruments used in this study, namely The Adolescent Resilience Scale which was compiled by Oshio et al., [16] and adapted by the author into the Adolescent Resilience Scale so that it can be used on research subjects with reliability of 0.791 which is included in the high category (table 1).

The social support variable is measured by the Multidimensional Scale of Perceived Social Support (MSPSS) compiled by Zimet et al., [22] and has been adapted by Eva \& Bisri, [24] with a reliability of 0,787 which includes the high category (table 2). Three components measured using the Multidimensional Scale of Perceived Social Support 
TABLE 1: The Adolescent Resilience Scale Reliability.

\begin{tabular}{l|lc|ll} 
Variable & Aitem & $\begin{array}{l}\text { Value } \\
\text { Cronbach } \\
\text { try out }\end{array}$ & $\begin{array}{r}\text { Alpha } \\
\text { After }\end{array}$ \\
& $\begin{array}{llll}\text { Before } \\
\text { Out }\end{array}$ & Try After Try Out & \\
Resilience & 21 & 14 & 0.791 &
\end{tabular}

TABLE 2: The Multidimensional Scale of Perceived Social Support (MSPSS) Reliability.

\begin{tabular}{l|ll|ll} 
Variable & Aitem & $\begin{array}{l}\text { Value } \\
\text { Cronbach } \\
\text { try out }\end{array}$ & $\begin{array}{r}\text { Alpha } \\
\text { After }\end{array}$ \\
& $\begin{array}{l}\text { Before } \\
\text { out }\end{array}$ & try After try out & \\
Social Support & 12 & 11 & 0.787
\end{tabular}

(MSPSS) are the family component, the component of friends, and the component of other influential people.

The data analyzed is data from a scale trial of 110 subjects. Data analysis was conducted to test the hypothesis, this research hypothesizes that there is a relationship between social support and resilience in students who memorize the Qur'an at SMP ISR Malang City. Testing the research hypothesis using the Pearson correlation approach with the help of SPSS 16.0 for windows.

\section{Results and Discussion}

The results of the analysis show that the Pearson product-moment analysis obtained a coefficient between the variables of social support and resilience of 0.675 with a significance or p-value of 0.05 . From the results of the analysis, it can be said that the research is $H_{0}$ is rejected and $H_{1}$ accepted $(p<0.05)$. The correlation value on the social support and resilience variables is positive so that the direction of the relationship between the two variables is unidirectional, which means that the higher the social support for students memorizing the Qur'an at SMP ISR Malang City, the higher the resilience in students memorizing the Qur'an at SMP ISR Malang City. The Pearson correlation in this study is 0.675 when referring to the Correlation Coefficient table. According to Sugiyono, the correlation coefficient is included in the high category [25]. Thus, it can be concluded that there is a relationship between social support and resilience, which has a positive direction on students memorizing the Qur'an at SMP ISR Malang City. 
In general, social support for students who memorize the Qur'an at SMP ISR Malang City is included in the high category as evidenced by the average score (mean) on the social support scale of 57.42 with a sample of 110 students. This shows that most students who memorize the Qur'an at SMP ISR Malang City have and feel that they have high social support, most of the students are in the high category with a percentage of $53.6 \%$ or 59 students, the rest are in the very high category with a percentage by $34.5 \%$, or 38 students, the sufficient category with a percentage of $9.1 \%$ or as many as 10 students, and the low category with a percentage of $2.7 \%$ or as many as 3 students.

Social support is a support that refers to the act of providing assistance or comfort from a person or group to others [19]. The level of social support is influenced by the components that make up social support, as Zimet et al., stated that the component includes, the presence of support that comes from family, friends, and other influential people [22]. Social support received by students, especially support from parents cannot be felt directly and with high intensity, this is because communication cannot be done intensely between students with their parents because daily students are not allowed to bring communication tools and meet with their parents when they visit is carried out, every month, namely on the second week on Saturday. However, through the results of the analysis, it was found that social support for students with poor conditions is on a high cathegory.

High social support will indirectly reduce the level of stress experienced by a person by mediating one's psychological resilience [26]. This is under the author's findings when collecting data, that although students are far from their parents, teachers and all teaching staff of SMP ISR Malang City embrace their students so that they always feel supported under any conditions, this was also conveyed through the author's interview with the principal of SMP ISR Malang City stated that the formation of various extracurricular activities that functioned to support them in developing themselves, on the other hand when they were in the process of memorizing the Qur'an, support from the teacher continued to be given so that students did not feel inferior to their friends and were down when their memorization was lost or forgotten.

In this study, some students at SMP ISR Malang City have a high level of social support, this is good because it helps them in carrying out their lives as students, especially when they feel down when they forget to memorize their Qur'an.

In general, the resilience of the students of SMP ISR Malang City who are in the process of memorizing the Qur'an is included in the high category with an average (mean) of 53.01. this shows that most of the students who are in the process of memorizing the Qur'an have a high level of resilience, in addition to the data that has 
been analyzed, it is found that as many as $45.5 \%$ or as many as 50 students from 110 research subjects have a high level of resilience, the rest are in the very high category. with a percentage of $40.9 \%$ or as many as 45 students, a sufficient category with a percentage of $10 \%$ or as many as 11 students, a low category with a percentage of $2.7 \%$ or as many as 3 students, and a very low category of $9 \%$ or 1 student.

Resilience is an individual's ability to overcome and adapt to adversity that occurs to him and will survive the adversity that occurs in his life [27]. High and low levels of resilience in student's memorizers of the Qur'an SMP ISR Malang in terms of some of the components that make up the concept of resilience, Oshio et al, mentions components that make up the resilience is Novelty Seeking, Emotion Regulation, Positive Future Orientation [16]. Resilience is reflected in how students who memorize the Qur'an continue to complete their memorization until in the end, they graduate as alumni of SMP ISR Malang City, even though on the way when they are memorizing the Qur'an there are many obstacles they experience, one of the obstacles that make them most depressed is when students will deposit their memorization. but they forgot to memorize it.

Resilience is influenced by several factors both internally and externally. Herrman et al., stated that the factors that influence resilience are personality factors and biological factors which are included in internal factors, and environmental factors are included in external factors [18]. On external factors, social support for positive peer relationships, in the realm of students memorizing the Qur'an at SMP ISR, from the results of the author's interview with one of the students, positive peers are described as examples of friends who help listen to the memorization of other friends and strengthen each other with one another. others so that their memorization is not lost. Other external factors, namely supportive teachers, such as the efforts of clerics and clerics at SMP ISR Malang City in encouraging students to remain consistent in wanting to memorize the Qur'an, close family, and other adults are some of the components that affect individual resilience.

From the author's interview with students memorizing the Qur'an at SMP ISR Malang City, resilience is reflected in their ability to overcome difficulties or misfortunes and rise from their adversity when their memorization is lost or they are difficult to add to their memorization, even though there are many obstacles they face, such as the density of cottage activities. pesantren especially when they participate in extracurricular activities and additional activities such as the Olympics can overcome these obstacles which are shown by their efforts to continue to memorize the Qur'an.

This study was conducted to examine the relationship between social support and resilience in students memorizing the Qur'an at SMP ISR Malang City. Based on the 
results of the analysis that has been carried out, it is known that the hypothesis in this study is accepted, it can be interpreted that there is a relationship between social support variables and resilience variables in students who memorize the Qur'an at SMP ISR Malang. The correlation test between the two variables produces a coefficient of 0.675 ( $p<0.05$ ), meaning that it belongs to the high category and the direction of the relationship is positive, namely the higher the social support possessed by students, the higher their level of resilience, and vice versa the lower the social support they receive. owned by students, the lower the resilience possessed by students. These results support the research conducted by Oktaviana with the research subject being deaf teenagers at Pelita Special School, Bayur Special School, Untung Tuah Special School. It was found that the results of research on the relationship between social support and resilience correlate 0.572 , meaning the higher the level of social support so the resilience is high [28].

Previous literature conducted by Lee et al., with immigrant participants in the United States, shows that United States politics that discriminate against Latino immigrants makes them fearful of deportation so that they access the community for social support [29]. This study looks at whether social support and loneliness can shape immigrants into resilient individuals. The results of this study show that social support is positively correlated with $r=0.16, p<0.1$, so that when social support for immigrants is high, the level of resilience tends to be high as well.

\section{References}

[1] Putri AS, Uyun Q. HUBUNGAN TAWAKAL DAN RESILIENSI PADA SANTRI REMAJA PENGHAFAL AL QURAN DI YOGYAKARTA. Jurnal Psikologi Islam. 2017 Sep 1;4(1):7787.

[2] Subandi MA, Chairani L. Psikologi santri penghafal Al-Qur'an?: peranan regulasi diri. 1st ed. Yogyakarta: Pustaka Pelajar; 2010 [cited 2021 Nov 30]. 297 p.

[3] Hendriani W. Resiliensi Psikologis: Sebuah Pengantar. Jakarta: Kencana; 2018. 225 p.

[4] Santrock J. Life-Span Development. New York: McGraw-Hill Education; 2010. 800 p.

[5] Addonizio FP. Stress, coping, social support, and psychological distress among MSW students [Internet] [Ph.D.]. ProQuest Dissertations and Theses. [United States South Carolina]: University of South Carolina; 2011 [cited 2021 Dec 1]. Available from: https://www.proquest.com/docview/905163879/abstract/42952F617EFB4091PQ/1 
[6] Marhamah F, Hamzah HB. THE RELATIONSHIP BETWEEN SOCIAL SUPPORT AND ACADEMIC STRESS AMONG FIRST YEAR STUDENTS AT SYIAH KUALA UNIVERSITY. PJP. 2017;1(1):149-172.

[7] Bokhorst CL, Sumter SR, Westenberg PM. Social Support from Parents, Friends, Classmates, and Teachers in Children and Adolescents Aged 9 to 18 Years: Who Is Perceived as Most Supportive? Social Development. 2010 May;19(2):417-26. doi: 10.1111/j.1467-9507.2009.00540.x

[8] Stice E, Ragan J, Randall P. Prospective Relations Between Social Support and Depression: Differential Direction of Effects for Parent and Peer Support? Journal of Abnormal Psychology. 2004;113(1):155-9. doi: 10.1037/0021-843X.113.1.155

[9] Baron RA, Byrne DE. Social psychology. 8th ed. Boston: Allyn and Bacon; 2013. 640 p.

[10] Taylor SE. Social Support: A Review [Internet]. Oxfordshire: Oxford University Press; 2011 [cited 2021 Dec 1]. Available from: http://oxfordhandbooks.com/view/10.1093/ oxfordhb/9780195342819.001.0001/oxfordhb-9780195342819-e-009

[11] Baron RA, Branscombe NR. Social Psychology. New Jersey: Pearson; 2012. 509 p.

[12] Rojas F. LF. Factors Affecting Academic Resilience in Middle School Students: A Case Study. GIST. 2015 Dec 14;(11):63-78. doi: 10.26817/16925777.286

[13] Sambu LJ. An investigation of the relationship between internal and external factors and resilience of internally displaced persons after the experience of trauma?: a case study of Kiambaa Village in Eldoret East sub-county in Uasin Gishu County, Kenya [Unpublished doctoral dissertation]. University of South Africa, Pretoria

[14] Grotberg EH. Resilience for Today: Gaining Strength from Adversity. Connecticut: Greenwood Publishing Group; 2003. 302 p.

[15] Prince-Embury S, Saklofske DH, Nordstokke DW. The Resiliency Scale for Young Adults. Journal of Psychoeducational Assessment. 2017 Jun;35(3):276-90. doi: $10.1177 / 0734282916641866$

[16] Oshio A, Kaneko H, Nagamine S, Nakaya M. Construct Validity of the Adolescent Resilience Scale. Psychol Rep. 2003 Dec;93(3_suppl):1217-22. doi: 10.2466/pr0.2003.93.3f.1217

[17] Oshio A, Taku K, Hirano M, Saeed G. Resilience and Big Five personality traits: A meta-analysis. Personality and Individual Differences. 2018 Jun;127:54-60. doi: 10.1016/j.paid.2018.01.048

[18] Herrman H, Stewart DE, Diaz-Granados N, Berger EL, Jackson B, Yuen T. What is Resilience? Can J Psychiatry. 2011 May;56(5):258-65. doi: $10.1177 / 070674371105600504$ 
[19] Sarafino EP, Smith TW. Health Psychology: Biopsychosocial Interactions. New Jersey: Wiley; 2020. 568 p.

[20] Malecki CK, Demary MK. Measuring perceived social support: Development of the child and adolescent social support scale (CASSS). Psychol Schs. 2002 Jan;39(1):118. doi: 10.1002/pits.10004

[21] Purba J, Yulianto A, Widyanti E, Esa D, Esa M. Pengaruh dukungan sosial terhadap burnout pada guru. Jurnal Psikologi. 2007;5(1):77-87.

[22] Zimet GD, Dahlem NW, Zimet SG, Farley GK. The multidimensional scale of perceived social support. Journal of personality assessment. 1988;52(1):30-41.

[23] Cohen JR. Social Support and Health. Cohen S, Syme SL, editors. Michigan: Academic Press; 1985. 416 p.

[24] Eva N, Bisri M. Dukungan Sosial, Religiusitas, dan Kesejahteraan Psikologis Mahasiswa Cerdas Istimewa. In: Proseding Seminar Nasional Klinis. Malang, Indonesia: Fakultas Pendidikan Psikologi; 26 August 2018.

[25] Sugiyono S. Metode penelitian pendidikan: (pendekatan kuantitatif, kualitatif dan R \& D). Jakarta: Alfabeta; 2008. book.

[26] Hu T, Xiao J, Peng J, Kuang X, He B. Relationship between resilience, social support as well as anxiety/depression of lung cancer patients: A cross-sectional observation study. J Can Res Ther. 2018;14(1):72. doi: 10.4103/jcrt.JCRT_849_17

[27] Reivich K, Shatté A. The Resilience Factor: 7 Essential Skills for Overcoming Life's Inevitable Obstacles. Oregon: Broadway Books; 2002. 358 p.

[28] Oktaviana A. Hubungan Locus of Control dan Dukungan Sosial dengan Resiliensi Pada Remaja Penyandang Tuna Rungu. Psikoborneo: Jurnal IImiah Psikologi. 2013 Jan 17;1(1):1-5. doi: 10.30872/psikoborneo.v111.3272

[29] Lee J, Hong J, Zhou Y, Robles G. The Relationships Between Loneliness, Social Support, and Resilience Among Latinx Immigrants in the United States. Clin Soc Work J. 2020 Mar;48(1):99-109. doi: 10.1007/s10615-019-00728-w 